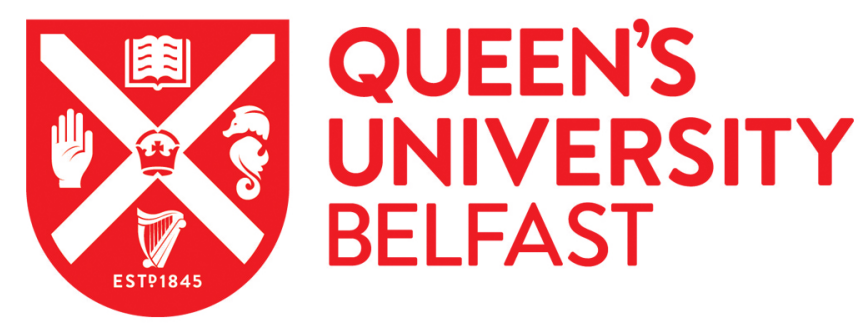

\title{
Composition of catalyst resting states of hydroformylation catalysts derived from bulky mono-phosphorus ligands, rhodium dicarbonyl acetylacetonate and syngas
}

How, R. C., Dingwall, P., Hembre, R. T., Ponasik, J. A., Tolleson, G. S., \& Clarke, M. L. (2017). Composition of catalyst resting states of hydroformylation catalysts derived from bulky mono-phosphorus ligands, rhodium dicarbonyl acetylacetonate and syngas. Molecular Catalysis, 434, 116-122.

https://doi.org/10.1016/j.mcat.2017.01.030

\section{Published in:}

Molecular Catalysis

\section{Document Version:}

Peer reviewed version

Queen's University Belfast - Research Portal:

Link to publication record in Queen's University Belfast Research Portal

\author{
Publisher rights \\ (C) 2017 Elsevier B. V. This manuscript version is made available under the CC-BY-NC-ND 4.0 license \\ http://creativecommons.org/licenses/by-nc-nd/4.0/, which permits distribution and reproduction for noncommercial purposes, provided the \\ author and source are cited
}

\section{General rights}

Copyright for the publications made accessible via the Queen's University Belfast Research Portal is retained by the author(s) and / or other copyright owners and it is a condition of accessing these publications that users recognise and abide by the legal requirements associated with these rights.

Take down policy

The Research Portal is Queen's institutional repository that provides access to Queen's research output. Every effort has been made to ensure that content in the Research Portal does not infringe any person's rights, or applicable UK laws. If you discover content in the Research Portal that you believe breaches copyright or violates any law, please contact openaccess@qub.ac.uk. 


\title{
Composition of catalyst resting states of hydroformylation catalysts derived from bulky mono-phosphorus ligands, rhodium dicarbonyl acetylacetonate and syngas.
}

Rebecca C. How ${ }^{\mathrm{a}}$, Paul Dingwall ${ }^{\mathrm{a}}$, Robert T. Hembre ${ }^{\mathrm{b}}$, James A. Ponasik ${ }^{\mathrm{b}}$, Ginette S. Tolleson $^{\mathrm{b}}$ and Matthew L. Clarke ${ }^{\mathrm{a} *}$

${ }^{a}$ School of Chemistry, University of St Andrews, EaStCHEM, St Andrews, Fife, UK, KY16 9ST. Fax: +44 (0)1334 463808; Phone: +44 (0)1334 463850, email: mc28@st-andrews.ac.uk

b Eastman Chemical Company, 200 South Wilcox Drive, Kingsport, Tennessee, 37660, USA

\begin{abstract}
The paper describes the composition of the resting states of several catalysts for alkene hydroformylation derived from bulky monophosphorus ligands. The results presented assess how bulky ligands compete with $\mathrm{CO}$ for the rhodium, and hence the role of 'unmodified' catalysts in alkene hydroformylation in the presence of these ligands. High Pressure Infra-Red (HPIR) spectroscopy was carried out at the rhodium and syngas concentrations typically used during catalysis experiments. These HPIR studies revealed that two ligands previously studied in $\mathrm{Rh}$-catalysed hydroformylation react with $\left[\mathrm{Rh}(\mathrm{acac})(\mathrm{CO})_{2}\right]$ and $\mathrm{H}_{2} / \mathrm{CO}$ to give the unmodified rhodium cluster, $\left[\mathrm{Rh}_{6}(\mathrm{CO})_{16}\right]$, as the only detectable species. Both less bulky phosphoramidites, and 1,3,5,7-Tetramethyl-6-phenyl-2,4,8-trioxa-6-phosphaadamantane, on the other hand, do not show the presence of $\left[\mathrm{Rh}_{6}(\mathrm{CO})_{16}\right]$, and hence catalysis proceeds by purely ligand modified species under normal conditions. In the case of the $\mathrm{Rh} /$ phosphaadamantane catalysts, anecdotal evidence that this only forms a particularly useful catalyst above a certain pressure threshold can be understood in terms of how the catalyst composition varies with pressure. The ligands discussed have all been assessed in the hydroformylation of propene to separate their innate branched selectivity from their ability to isomerise higher alkenes to internal isomers.
\end{abstract}


Keywords: hydroformylation; unmodified catalysts; in situ monitoring; phosphoramidites; IR spectroscopy

\section{Introduction}

As is often remarked, hydroformylation of alkenes is one of the most important reactions in homogenous catalysis. Rh catalysts derived from bidentate ligands are particularly useful for linear-selective hydroformylation of terminal alkenes, and, generally using substrates biased towards branched products, asymmetric hydroformylation.[1,2] Bulky monophosphorus ligands have also played a prominent role in hydroformylation catalysis. Bulky phosphites are known to give remarkably active catalysts. Detailed studies of ortho-substituted triarylphosphite systems show that, while a mixture of Rh species can be formed during hydroformylation, the high reactivity and high isomerisation activity can be ascribed to mono-ligated rhodium catalysts.[3] The resting state of a mono-ligated pathway is a complex of type $\left[\mathrm{Rh}(\mathrm{H}) \mathrm{L}(\mathrm{CO})_{3}\right]$. In situ spectroscopic studies have also been carried out on some supramolecular assemblies formed from bulky monodentate phosphoramidites; these also form mono-ligated catalysts of type $\left[\mathrm{Rh}(\mathrm{H}) \mathrm{L}(\mathrm{CO})_{3}\right]$. [4] These are in contrast to less reactive catalysts derived from less bulky triphenylphosphine and triphenylphosphite that tend to form a complex mixture of resting states: $\left[\mathrm{Rh}(\mathrm{H}) \mathrm{L}(\mathrm{CO})_{3}\right],\left[\mathrm{Rh}(\mathrm{H}) \mathrm{L}_{2}(\mathrm{CO})_{2}\right]$ (2 isomers), $\left[\mathrm{Rh}(\mathrm{H}) \mathrm{L}_{3}(\mathrm{CO})_{1}\right]$ in varying proportions depending on the reaction conditions.[5] Carbonyl clusters with bridging carbonyl ligands and coordinated phosphorus ligands can also form, although these can be converted back to the hydride-carbonyl complexes above under hydroformylation conditions. Finally, all of these species can potentially be in competition with unmodified Rh catalysts, $\left[\mathrm{Rh}(\mathrm{H})(\mathrm{CO})_{4}\right]$ or $\left[\mathrm{Rh}_{6}(\mathrm{CO})_{16}\right]$.

There are other interesting reports describing performance in hydroformylation for other types of $\mathrm{Rh} /$ bulky monophosphorus ligand catalysts. However, few of these have been interrogated spectroscopically. In connections with our work aimed at developing alkene hydroformylations with branched regioselectivity,[6] we wished to identify if certain ligand types were worthy of further development: three catalysts derived from bulky monophosphrous ligands seemed to us to require greater understanding of catalyst composition.

Ojima and co-workers [7] reported the use of enantiopure mono-dentate phosphoramidites in the enantioselective hydroformylation of allyl cyanide. Allyl 
cyanide does tend to give preference for the branched aldehyde $[7,8]$ but the regioselectivity reported for ligand 1 is unusually high (B:L 96:4). Related ligand 2 gave no enantioselectivity and reduced regioselectivity. Another paper reporting unusual branched regioselectivity used trinaphthylphosphine, ligand 1-Np3 P.[9] However, in this work on 1-hexene hydroformylation, extensive isomerisation occurs,

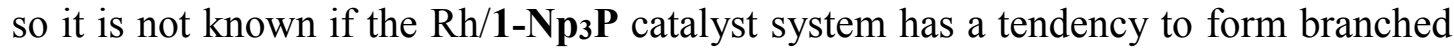
aldehydes, or that the products almost exclusively stem from hydroformylation of the isomerised alkenes hex-2-ene and hex-3-ene. The adamantyl cage phosphine, 1,3,5,7Tetramethyl-6-phenyl-2,4,8-trioxa-6-phosphaadamantane, ${ }^{M e} \mathbf{C g P - P h}$ has been used often, as its $\mathrm{Rh}$ catalyst has several desirable characteristics: air and moisture stable during reaction set up, ability to hydroformylate less reactive highly substituted alkenes, high reactivity and a tendency to form an unusually large amount of branched products in the hydroformylation of hex-1-ene.[6b,6d,6e] However, unlike a lot of hydroformylation catalysts that operate best at low pressures (2-10 bar), we have observed on many occasions that $\mathrm{Rh} /{ }^{\mathrm{Me}} \mathbf{C g P}-\mathbf{P h}$ catalysts do not readily exhibit their best performance until at least 10 bar of syngas pressure (at the concentration and temperatures they are typically used at).

During hydroformylation using strong chelating bidentate ligands, providing the ligands are used in $>1: 1$ ratio to rhodium, there is no contribution from 'unmodified catalysts' (with no ligands present except carbon monoxide and hydrogen). This means that catalyst resting states have often been studied using NMR spectroscopy backed up by IR spectroscopy, and in some cases catalyst resting states have been isolated and fully characterised. It is important to note that using monophosphorus ligands this is not the case. An equilibrium exists under hydroformylation conditions in which many resting states can co-exist, and indeed each of these could lead to a distinct catalytic cycle that produces product. This includes the unmodified $\mathrm{Rh}$ catalysts which could also contribute towards forming aldehyde products. A key aspect of this equilibrium is controlled by the concentration of $\mathrm{CO}$ and phosphorous ligand. In order to shed light on which cycles are dominant during hydroformylation, it is important to study the catalyst resting states under similar conditions to those used in a hydroformylation reaction: these are generally too dilute to study using NMR spectroscopy. In particular while NMR characterisation can be performed on the reaction between a $\mathrm{Rh}$ precursor, syngas and ligands at high concentrations, this pushes the equilibrium away from unmodified species and towards the more highly 
ligated compounds. We wished to assess if: (i) the bulky monophosphoramidites can sometimes form both unmodified catalysts and ligated catalytic pathways, (ii) if

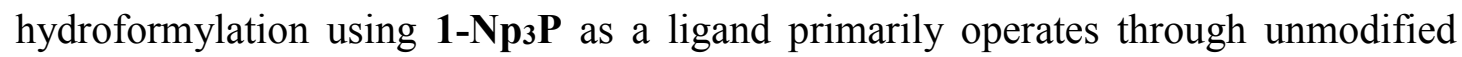
catalysts, (iii) whether the ${ }^{\mathrm{Me}} \mathbf{C g P}-\mathbf{P h}$ ligand exclusively forms mono-ligated catalysts, or has a contribution from unmodified species, and why $>10$ bar syngas pressure is generally required. In this project, we have carried out HPIR studies under conditions close to those used in catalysis to shed light on the number the phosphorus ligands coordinated to rhodium during hydroformylation. We also report the use of the ligands in Fig. 1 in rhodium-catalysed hydroformylation of propene.<smiles>[R]N([R])P(Oc1c(C)cc(C)cc1C(C)(C)C)Oc1c(C(C)(C)C)cc(C)c(C)c1-c1ccccc1C</smiles>

1: $\mathrm{R}=\mathrm{Me}$

2: $\mathrm{R}=\mathrm{i} \mathrm{Pr}$<smiles>c1ccc2c(P(c3cccc4ccccc34)c3cccc4ccccc34)cccc2c1</smiles>

$1-\mathrm{Np}_{3} \mathrm{P}$<smiles>Cc1cc(C)c2c(c1)Cc1cc(C)cc(C)c1OP(N(C)C)O2</smiles>

3<smiles>CC12OC3(C)OC(C)(O1)C(C)(O2)P3c1ccccc1</smiles>

${ }^{\mathrm{Me}} \mathrm{CgP}-\mathrm{Ph}$

Figure 1: Structures of ligands used in this study

\section{Results and Discussion}

The majority of the ligands examined in this study were well known and prepared according to the literature or purchased. However, ligand $\mathbf{3}$ is a new compound and was fully characterised. The ligands were tested in the hydroformylation of propene to see if the catalysts derived from these ligands demonstrated unusually high isoselectivity (Table 1); over 50\% branched selectivity is near to the state of the art; few catalysts have been reported to give higher iso-selectivity than simple unmodified catalysts. The use of $\left[\mathrm{Rh}(\mathrm{acac})(\mathrm{CO})_{2}\right]$ without added ligand gives around $56 \%$ 
branched selectivity, similar to the more bulky of the ligands 1-Np3 P and $\mathbf{2}$. The TON measured after one hour is an average TOF; this measure of conversion at this arbitrary point in time provides a useful estimation of activity, although these values are not initial turnover frequencies, since some of these reactions are nearing completion, while some are near their peak rate after one hour $(100 \%$ conversion corresponds to TON from gas uptake of $\sim 1350$ ). This was sufficient to show that the

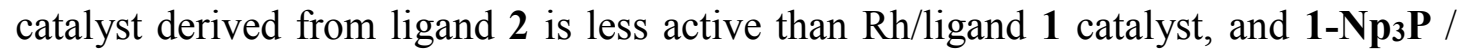
$\mathrm{Rh}$ is a less active catalyst than less bulky $\mathrm{PPh}_{3} / \mathrm{Rh}$ catalysts.

Table 1: Hydroformylation of propene

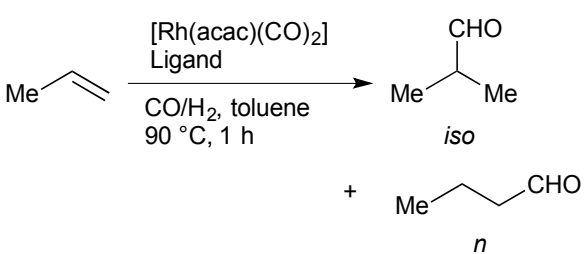

\begin{tabular}{|c|c|c|c|}
\hline Entry & Ligand & TON & $\%$ iso \\
\hline $1^{\mathrm{a}}$ & none & 684 & 56 \\
\hline $2^{b}$ & none & 590 & 56 \\
\hline 3 & 1 & 1023 & 48 \\
\hline 4 & 2 & 712 & 54 \\
\hline 5 & 3 & 542 & 37 \\
\hline 5 & $\mathbf{P P h}_{3}$ & 903 & 37 \\
\hline 6 & $1-\mathrm{Np}_{3} \mathrm{P}$ & 124 & 57 \\
\hline 7 & ${ }^{\mathrm{Me}} \mathrm{CgP}-\mathrm{Ph}$ & 1013 & 41 \\
\hline
\end{tabular}

$\left[\mathrm{Rh}(\mathrm{acac})(\mathrm{CO})_{2}\right](5.12 \mu \mathrm{mol})$ and ligand $(0.020 \mathrm{mmol})(\mathrm{Rh}: \mathrm{L} 1: 4)$ stirred in toluene $(20 \mathrm{~mL})$ at $90{ }^{\circ} \mathrm{C}$ under syngas $\left(\mathrm{CO}: \mathrm{H}_{2} 1: 1\right.$, 20 bar) for 1 hour, prior to running reaction for 1 hour under propene/syngas (20 bar (Propene:hydrogen:CO = 2:9:9). Products determined by GC using 1-methylnaphthalene as an internal standard. ${ }^{a}$ Pre-Catalyst $=\left[\mathrm{Rh}(\mathrm{acac})(\mathrm{CO})_{2}\right]$ no ligand. ${ }^{\mathrm{b}}$ Pre-Catalyst $=\left[\mathrm{Rh}_{2}(2 \text {-ethylhexanoate })_{4}\right]$, no ligand.

HPIR spectroscopy has often been used successfully to confirm the structures of Rh catalysts derived from bis-phosphorus ligands.[10] In these cases, the main species are limited to bis-equatorial isomers and axial-equatorial isomers, along with some inactive resting states. These are often independent of catalyst concentration. As previously discussed, it is common for many mono-phosphorus ligands to form quite 
complex catalyst compositions. Our primary aim was to assess if the unmodified catalysts were formed for any of the ligands, but to also get a snapshot of the types of resting state that were favoured. In this study, we were able to get good spectra at concentrations of [1-2 mM]: similar to those used in catalysis (Ref. 7: $1 \mathrm{mM}$; Ref 9: $0.23 \mathrm{mM})$.

$\left[\mathrm{Rh}_{6}(\mathrm{CO})_{16}\right]$ has large carbonyl stretching vibrations at 2074 and $1821 \mathrm{~cm}^{-1}$ with a weak band at $2045 \mathrm{~cm}^{-1}$.[11] An IR spectrum of a sample generated under our conditions is archived in the ESI and is in agreement with the above assignment. This can be formed from $\left[\mathrm{Rh}(\mathrm{acac})(\mathrm{CO})_{2}\right]$ or from $\left.\left[\mathrm{Rh}_{2} \text { (hexanoate }\right)_{4}\right]$. Garland and coworkers [12] have demonstrated that $\left[\mathrm{Rh}_{4}(\mathrm{CO})_{12}\right]$ and $\left[\mathrm{Rh}_{6}(\mathrm{CO})_{16}\right]$ converts into $\left[\mathrm{RhH}(\mathrm{CO})_{4}\right]$ during studies on the hydroformylation of dimethylbut-1-ene.

There is some useful literature on the position of the carbonyl absorption bands for Rh catalysts derived from certain ligands that give relatively simple catalyst compositions under the conditions of the HPIR experiment.[1,4,5a,10] [ $\left.\mathrm{RhH}(\mathrm{CO})_{2}\left(\mathrm{PPh}_{3}\right)_{2}\right]$ with $\mathrm{PPh}_{3}$ in the axial and equatorial positions contains bands at 1992 and $1947 \mathrm{~cm}^{-1}$ in 2methyltetrahydrofuran at around $60 \mathrm{mM}$ concentration.[1,5a] The bis-equatorial species is assigned to bands at 2042 and $1981 \mathrm{~cm}^{-1}$. Triphenylphosphite forms the 2 isomers of $\left[\mathrm{RhH}(\mathrm{CO})_{2}\left(\mathrm{P}(\mathrm{OPh})_{3}\right)_{2}\right]$ displaying carbonyl stretches at 2034 and 1992 $\mathrm{cm}^{-1}$ for the axial equatorial isomer, and 2053 and $2018 \mathrm{~cm}^{-1}$ for the bis-equatorial isomer. $\left[\mathrm{RhH}(\mathrm{CO})\left(\mathrm{P}(\mathrm{OPh})_{3}\right)_{3}\right]$ has also been detected with a stretch at $2070 \mathrm{~cm}^{-1}$. [5b] As expected, the electron-withdrawing ligand shifts the carbonyl stretches to higher wavenumber. A mono-ligated $\mathrm{Rh}$ complex of a phosphoramidite ligand shows bands at 2054, 2000 and $1982 \mathrm{~cm}^{-1}$ if the phosphorus ligand is in the equatorial plane and 2055, 2022, $1998 \mathrm{~cm}^{-1}$ if the phosphorus ligand is in the apical position.[4d] With these comparisons in hand, most of the components (unmodified cluster, mono or bisligated $\mathrm{Rh}$ complexes) in the catalyst mixtures can be assigned, and the presence of the unmodified clusters can be unequivocally determined.

The catalysts formed from ligand $\mathbf{1}$ and bulkier ligand, $\mathbf{2}$ were studied by in situ HPIR spectroscopy (Figure 3). The IR spectra obtained from [Rh(acac)(CO) $]$, ligand 1 and syngas shows a number of bands around 1950-2050 $\mathrm{cm}^{-1}$, typical for $\left[\mathrm{RhH}(\mathrm{CO})_{\mathrm{n}}(\mathrm{L})_{3-\mathrm{n}}\right]$ complexes. In particular, bands at 2062/2009 $\mathrm{cm}^{-1}$ and 2037/1996 $\mathrm{cm}^{-1}$ are suggestive of the two isomers of a bis-ligated species. In the original paper 
on the use of this ligand in enantiomerically pure form, DFT calculations supported a bis-ligated pathway, and this result is in agreement with this.

In contrast, the reaction of ligand $2,\left[\mathrm{Rh}(\mathrm{acac})(\mathrm{CO})_{2}\right]$ and syngas leads to almost exclusive formation of the rhodium cluster, $\left[\mathrm{Rh}_{6}(\mathrm{CO})_{16}\right]$ either at $70{ }^{\circ} \mathrm{C}$ and $90{ }^{\circ} \mathrm{C}$. In the previous work by Ojima and co-workers [7], the enantiomerically pure form of ligand $\mathbf{2}$ gave poorer regioselectivity and no enantioselectivity in hydroformylation. It therefore seems very likely that this bulky ligand does not coordinate to rhodium under hydroformylation conditions, and that the higher branched selectivity observed for propene hydroformylation with ligand 2 relative to ligand $\mathbf{1}$ (Table 1), is almost certainly due to the unmodified catalyst.

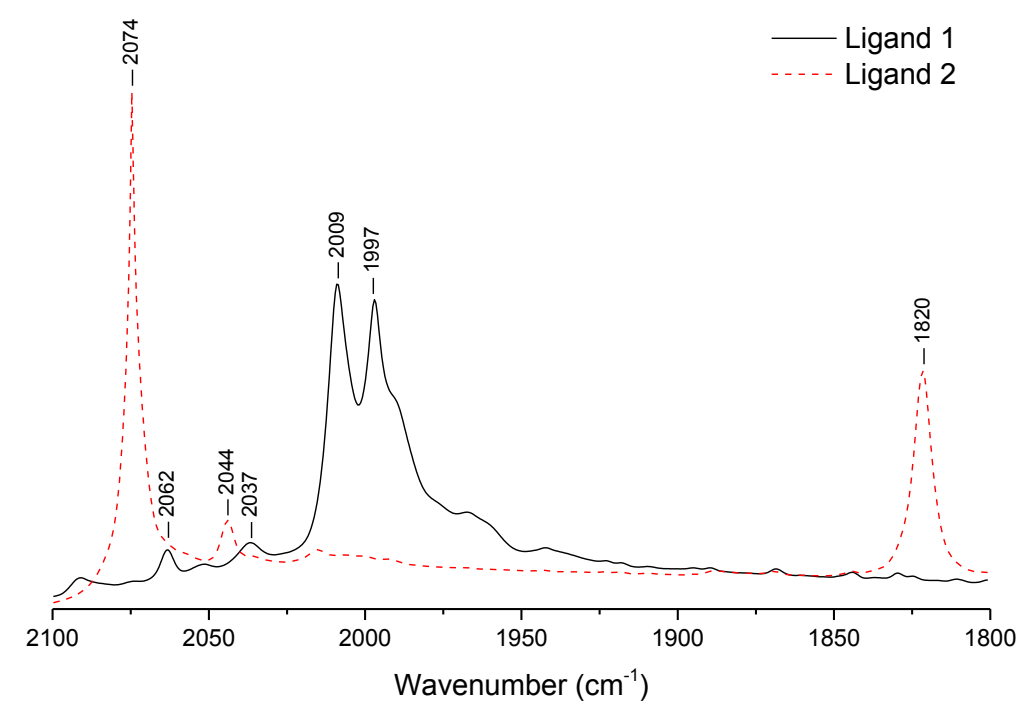

Fig. 3: HPIR spectra of rhodium catalysts from $\left[\mathrm{Rh}(\mathrm{acac})(\mathrm{CO})_{2}\right] 70^{\circ} \mathrm{C}$ in hexane, under 20 bar syngas (CO:H $1: 1)$; from ligand 1 (black) and ligand 2 (red)

The least bulky phosphoramidate ligand 3, was found to give the lowest branched selectivity. HPIR spectroscopy confirms that no rhodium clusters were formed. The carbonyl bands at $2061 / 2015 \mathrm{~cm}^{-1}$ and $2026 / 1983 \mathrm{~cm}^{-1}$ are assigned to both isomers of $\left[\mathrm{RhH}(\mathrm{CO})_{2}(\mathrm{~L})_{2}\right]$ (Figure 4). 


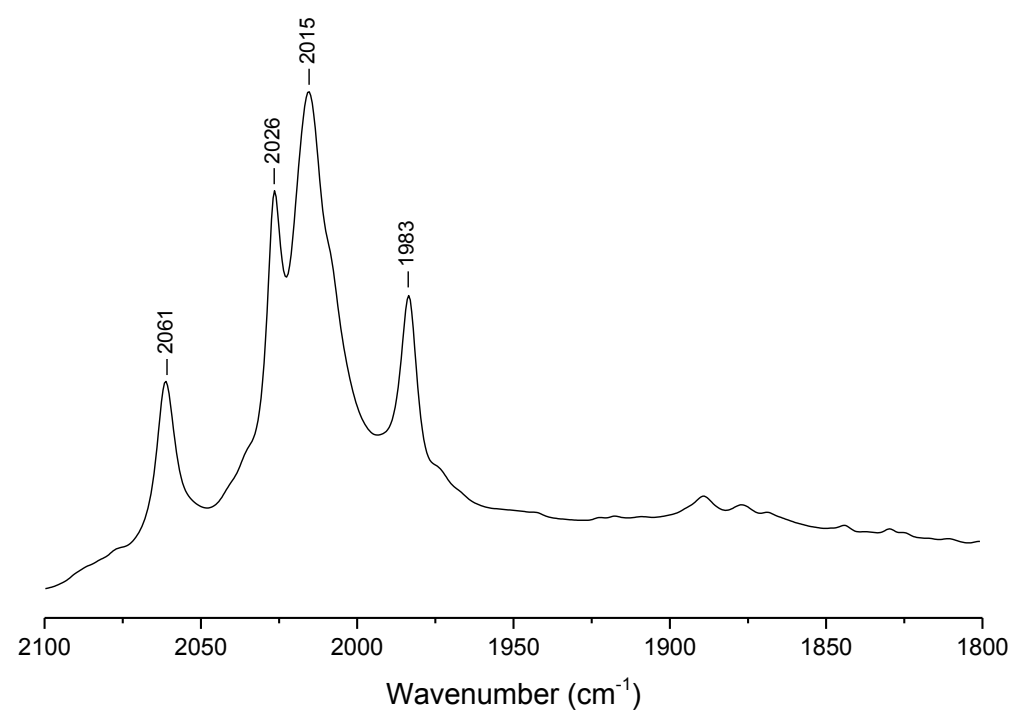

Figure 4: HPIR spectrum of rhodium catalysts formed from less bulky ligand, $\mathbf{3}$ at 70 ${ }^{\circ} \mathrm{c}$ and 20 bar syngas in hexane $(\mathrm{L}: \mathrm{Rh}=4: 1)$.

To provide a comparison under our conditions, the frequently used ligand $\mathrm{PPh}_{3}$ and $\left[\mathrm{Rh}(\mathrm{acac})(\mathrm{CO})_{2}\right]$ forms multiple catalyst species, with a number of carbonyl bands present between 1950-2060 $\mathrm{cm}^{-1}$ including both isomers of $\left[\mathrm{RhH}(\mathrm{CO})_{2}\left(\mathrm{PPh}_{3}\right)_{2}\right]$ as discussed in previous reports (see ESI).[1,5a] In contrast, $\left[\mathrm{Rh}(\mathrm{acac})(\mathrm{CO})_{2}\right], \mathbf{1 - N p} 3 \mathbf{P}$ and syngas react together to form only the rhodium cluster as the main detectable Rhcarbonyl species (Figure 5). 


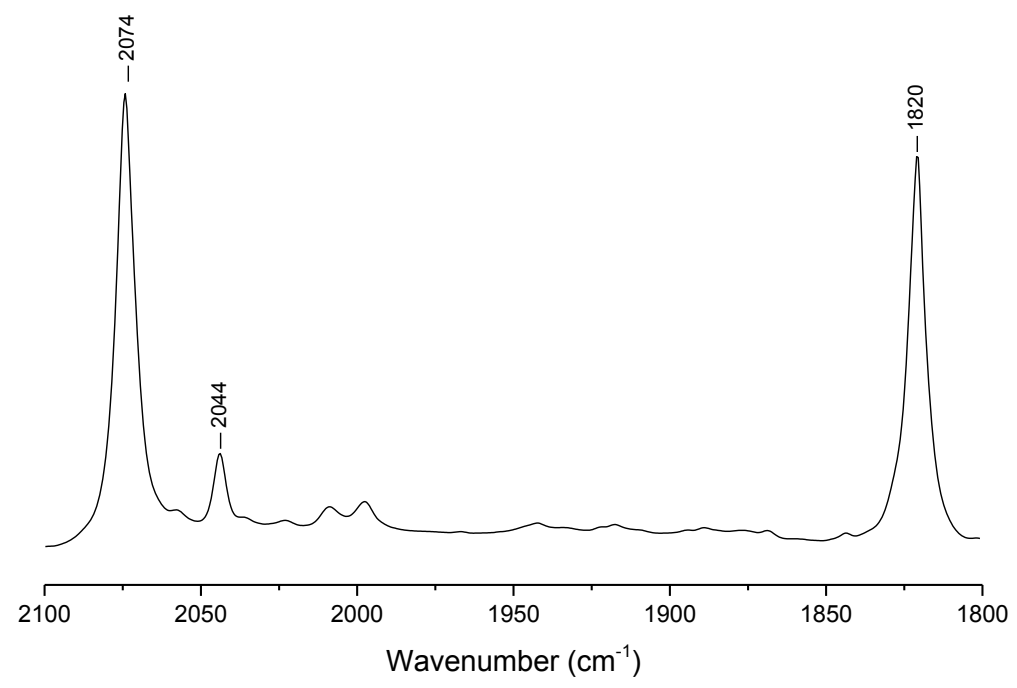

Figure 5: HPIR spectrum of rhodium catalyst formed with 1-Np3 $\mathbf{P}$ ligand at $70^{\circ} \mathrm{C}$ and 20 bar syngas in hexane $(\mathrm{L}: \mathrm{Rh}=4: 1)$; this matches that formed when no ligand is present and is assigned to $\left[\mathrm{Rh}_{6} \mathrm{CO}_{16}\right]$

It is very likely that the high branched selectivity observed for the hydroformylation of 1-hexene by Bajaj and co-workers [9] (as well the similar regioselectivities shown in propene hydroformylation using $\left[\mathrm{Rh}(\mathrm{acac})(\mathrm{CO})_{2}\right]$ alone) stems primarily or entirely from catalysis by the unmodified catalyst. The spectroscopic experiment on the $\mathrm{Rh} / \mathbf{1}$ $\mathbf{N p} 3 \mathbf{P}$ system was repeated at $110{ }^{\circ} \mathrm{C}$, the reaction temperature that was used in reference 9, and gave the same carbonyl bands in the IR spectrum. The 1-Np3 P ligand concentration in the HPIR experiment is slightly higher than that used in the propene hydroformylation. The known implication of higher ligand concentration is to form more ligand-associated species, and hence at low ligand and catalyst concentrations, unmodified catalysts resting states are even more likely. The lower activity observed relative to unmodified catalysts is most likely due to some inactive ligated $\mathrm{Rh}$ compound being present, at least at some point, and the effective concentration of

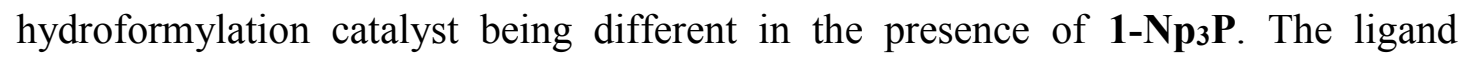
therefore can still have an impact on the catalysis, especially with higher alkenes where the regioselectivity is strongly influenced by the degree of alkene isomerisation that has occurred at a given point in the reaction, even if it doesn't coordinate to $R h$ during aldehyde formation. For the hydroformylation of higher alkenes especially then, some difference in the results observed in the presence of ligand between a 
control experiment of ligandless hydroformylation does not serve as evidence that the main catalysis going on is ligand modified. At the end of the reactions of $\left[\mathrm{Rh}(\mathrm{acac})(\mathrm{CO})_{2}\right]$ with syngas and ligands $\mathbf{1},{ }^{\mathbf{M e}} \mathbf{C g P}-\mathbf{P h}$ and $\mathbf{1 - N p} \mathbf{P} \mathbf{P}$, the reaction mixtures were concentrated and examined by ${ }^{31} \mathrm{P}\left\{{ }^{1} \mathrm{H}\right\}$ NMR. While the former two gave a mixture of compounds: the exact identity of which are not likely to be of particular significance to catalysis (since the composition is related to [CO]), there were several species that clearly displayed a JP-Rh coupling: these either directly represent (or are derived from) Rh catalysts formed from these ligands. In contrast,

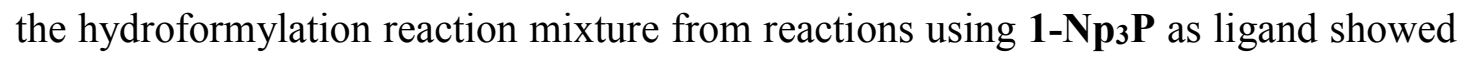
only free ligand $\left(\delta_{\mathrm{P}}=-32\right)$ and its oxide $\left(\delta_{\mathrm{P}}=+38\right)$. If a sample was taken from the reaction of $\mathbf{1 - N p} \mathbf{N}_{3} \mathbf{P}$ with $\left[\mathrm{Rh}(\mathrm{acac})(\mathrm{CO})_{2}\right]$ and syngas after a shorter time period there is a small amount of a $\mathrm{Rh}$ species formed, which can be assigned as $[\mathrm{Rh}(\mathrm{acac})(1$ $\left.\left.\mathrm{Np}_{3} \mathrm{P}\right)(\mathrm{CO})\right]\left(\delta_{\mathrm{P}}=46.5\right.$, br. $\left.\mathrm{d}, \mathrm{J}_{\mathrm{P}-\mathrm{Rh}}=173 \mathrm{~Hz}\right)$, which we also prepared independently (see ESI). We also monitored the reaction of $\left[\mathrm{Rh}(\mathrm{acac})\left(\mathbf{1}-\mathrm{Np}_{3} \mathbf{P}\right)(\mathrm{CO})\right], 3$ equivalents of 1-Np3 $\mathbf{P}$ and syngas by IR (this time using hexane $/ \mathrm{CH}_{2} \mathrm{Cl}_{2}$ mixture for solubility reasons) and found this converts into $\left[\mathrm{Rh}_{6}(\mathrm{CO})_{16}\right]$. There is a small additional carbonyl band observed at $1886 \mathrm{~cm}^{-1}$, but no sign of $\left[\mathrm{RhH}(\mathrm{CO})_{\mathrm{n}}(\mathrm{L})_{3-\mathrm{n}}\right]$ complexes. This peak cannot be assigned, and could be an inactive phosphine modified cluster, or

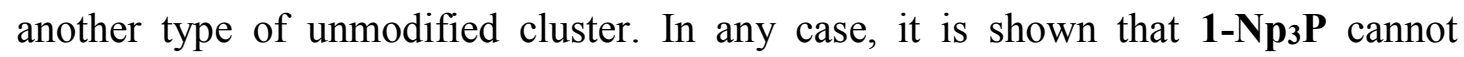
compete with the relatively high pressures of $\mathrm{CO}$ for $\mathrm{Rh}$ used under catalysis conditions.

The IR spectra obtained from $\left[\mathrm{Rh}(\mathrm{acac})(\mathrm{CO})_{2}\right],{ }^{\mathbf{M e}} \mathbf{C g P}-\mathbf{P h}$ and syngas were complex and a number of experiments were carried out, at increasing ligand concentration and syngas pressure, to assist in the assignment of the bands (Figure 6). Above an initial pressure of 5 bar syngas, an activation period of roughly 20 minutes was observed with formation of the activated species complete in a further 20 minutes. Below 5 bar of syngas pressure, catalyst activation to $\left[\mathrm{RhH}(\mathrm{CO})_{\mathrm{n}}(\mathrm{L})_{3-\mathrm{n}}\right]$ complexes does not take place. The rate at which the $\left[\operatorname{RhH}(\mathrm{CO})_{n}(\mathrm{~L})_{3-n}\right]$ species formed were observed to decrease as ligand loading increased and were sigmoidal in nature. Changes in adsorption band height were faster than the acquisition time of the experiment when the pressure of syngas was altered. 


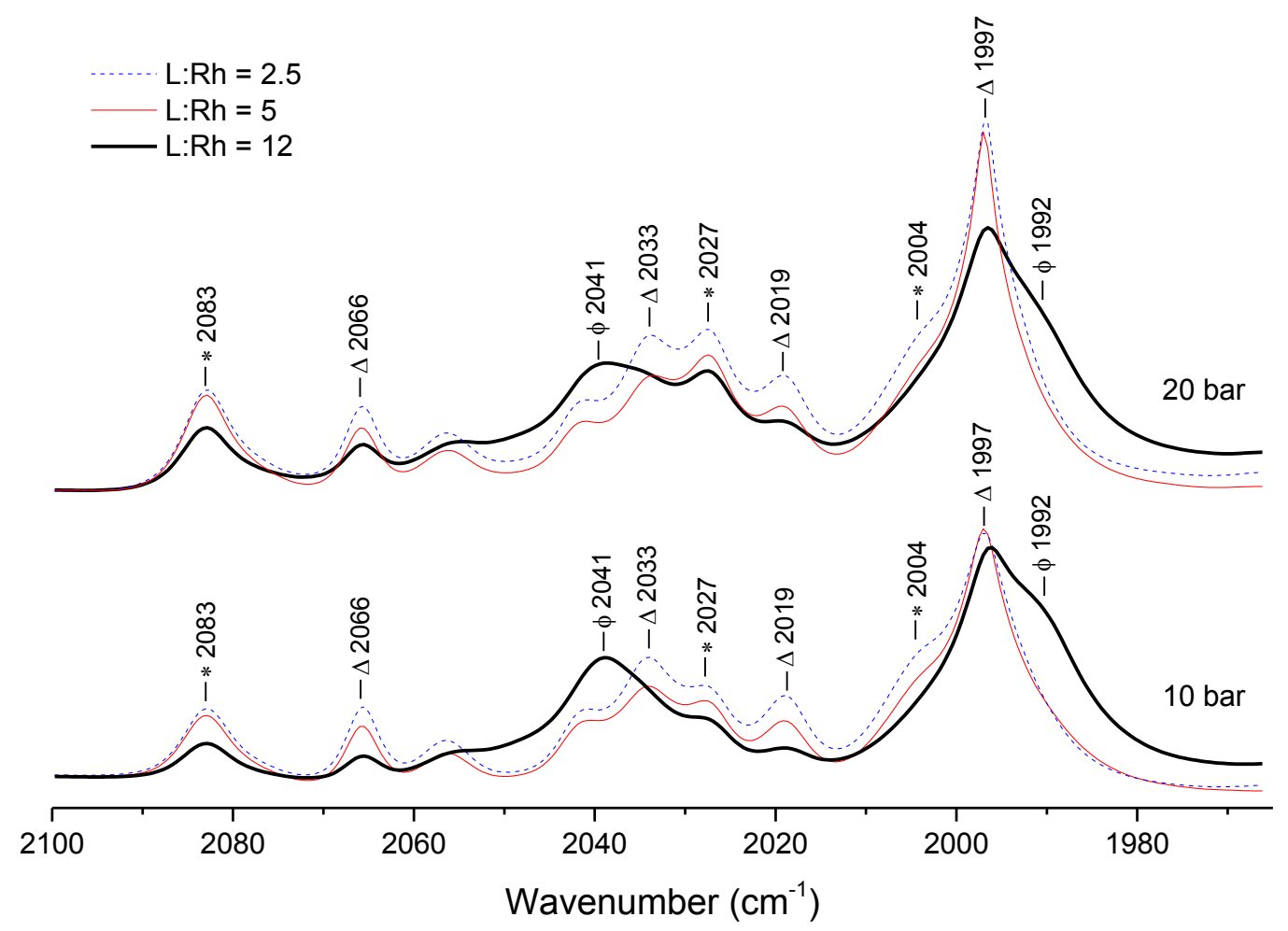

Fig. 6: HPIR spectra of rhodium catalysts from $\left[\mathrm{Rh}(\mathrm{acac})(\mathrm{CO})_{2}\right]$ at $50{ }^{\circ} \mathrm{C}$ in hexane, under 10 or 20 bar syngas (CO: $\mathrm{H}_{2}$ 1:1) with ${ }^{\mathbf{M e}} \mathbf{C g P - P h}$ at increasing loadings relative to rhodium; $\mathrm{L}: \mathrm{Rh}=2.5$ (blue), $\mathrm{L}: \mathrm{Rh}=5$ (red), $\mathrm{L}: \mathrm{Rh}=12$ (black). Assigned complexes are labelled mono $=*$, bis $=\Delta$, and tris $=\phi$.

At high ligand concentration $(\mathrm{L}: \mathrm{Rh}=12)$, the major species displayed one distinct adsorption bands at $2041 \mathrm{~cm}^{-1}$ that decreases in intensity on increasing pressure of syngas; we assign this as the tris-ligated complex (as the equilibrium between $\left[\mathrm{Rh}(\mathrm{H})(\mathrm{L})_{3}(\mathrm{CO})\right]$ and $\left[\mathrm{Rh}(\mathrm{H})(\mathrm{L})_{2}(\mathrm{CO})_{2}\right]$ and $\left[\mathrm{Rh}(\mathrm{H})(\mathrm{L})_{1}(\mathrm{CO})_{3}\right]$ should shift away from the former as the $\mathrm{CO}$ concentration is increased). A further correlated band is present at $1992 \mathrm{~cm}^{-1}$, we assign this as the possible hydride of the tris-ligated complex. At lower ligand concentration, major bands that decrease in intensity as the pressure of syngas increases are assigned as the two isomers of bis-ligated complexes, $\left[\mathrm{Rh}(\mathrm{H})(\mathrm{L})_{2}(\mathrm{CO})_{2}\right]$. Due to the differences in intensities of these stretches we assign 
2066 and $2019 \mathrm{~cm}^{-1}$ as the bis-equatorial complex and 2033 and $1997 \mathrm{~cm}^{-1}$ as the equatorial-axial complex. These are the shifts expected given the literature data on the bis-ligated complexes of $\mathrm{P}\left(\mathrm{OPh}_{3}\right)_{3}$.[5a,b] Finally, we assign bands at 2083, 2027, and $2004 \mathrm{~cm}^{-1}$ to the mono-ligated species, $\left[\mathrm{Rh}(\mathrm{H})(\mathrm{L})_{1}(\mathrm{CO})_{3}\right]$. These are present in the greatest amount at the lowest ligand concentration, $\mathrm{L}: \mathrm{Rh}=2.5$, and at each ligand concentration increase in intensity on increase in pressure of syngas. At each ligand concentration and pressure examined peaks at 1821, 1800, and $1779 \mathrm{~cm}^{-1}$ are observed, but there is no sign of the 3 correlated peaks that belong to $\left[\mathrm{Rh}_{6}(\mathrm{CO})_{16}\right]$. This suggests that while some form of bridging Rh-carbonyl species may indeed be a minor component in these reaction mixtures, there is no strong evidence for the unmodified catalyst being present to any great extent, and the reaction mixture is primarily composed of every possible type of $\left[\mathrm{Rh}(\mathrm{H})(\mathrm{L})_{\mathrm{n}}(\mathrm{CO})_{3-\mathrm{n}}\right]$ complex. Since higher pressure of syngas pushes the equilibrium towards $\left[\mathrm{Rh}(\mathrm{H})(\mathrm{L})_{1}(\mathrm{CO})_{3}\right]$ complexes, that are known for other ligands to be especially reactive, this is why the $\mathrm{Rh} /{ }^{\mathrm{Me}} \mathrm{CgP}-\mathrm{Ph}$ catalyst does not show significantly increased reactivity if the CO concentration is not high enough. This will be more pronounced for sterically hindered alkenes, and the combination of a relative low partial pressure of $\mathrm{CO}$ and a very small alkene in the propene hydroformylation experiments is probably why the ${ }^{\mathrm{Me}} \mathrm{CgP}-\mathrm{Ph} / \mathrm{Rh}$ catalysts gave broadly similar rates to $\mathrm{PPh}_{3} / \mathrm{Rh}$ catalyst in the propene hydroformylation experiments, while ${ }^{\mathrm{Me}} \mathbf{C g P}-\mathbf{P h} / \mathrm{Rh}$ catalysts are much more active under some conditions.[6c,d, 13]

\section{Conclusions}

A number of monodentate ligands have been investigated in the hydroformylation of propene. Two of the bulky ligands gave unusually high branched selectivity of propene, similar to what is observed with unmodified catalysts. However, this was due to the bulkier ligands dissociating from the rhodium, since under conditions similar to those used in catalysis using HPIR spectroscopy there was no evidence for phosphine modified catalysts. In hydroformylation using monodentate ligands the following equilibrium is set up (Scheme 1). For the bulky ligands 1-Np 3 P and 2, the equilibrium lies in the top right part of the scheme. For ligand 1, the evidence suggested that the main species formed was bis-ligated and hence able to control enantioselectivity in the similar way that these ligands have done before in 
asymmetric hydrogenation. For ${ }^{\mathbf{M e}} \mathbf{C g P}-\mathbf{P h}$, despite its significant bulk, it is able to form a mixture of ligand-modified species. This even includes the tri-ligated complex of type $\left[\mathrm{Rh}(\mathrm{H})(\mathrm{L})_{3}(\mathrm{CO})\right]$, generally considered to be unreactive. This species can be down-regulated by increases in $\mathrm{CO}$ pressure, allowing a greater concentration of highly reactive mono-ligated $\mathrm{Rh}$ species to predominate and deliver highly reactive catalysts. This shows the importance of ensuring ligand coordination has occurred when using monodentate ligands in hydroformylation. It is also now clear that despite some ligands significantly bulkier than 1 being used with success in other transition metal catalysed reactions, when they have to compete with the strong ligand $\mathrm{CO}$ the situation is different. The cage phosphine is a little different from the bulky phosphites and phosphoramidites known in that the highly reactive mono-ligated $\mathrm{Rh}$ catalysts are very much the major species reported, whereas ${ }^{\mathrm{Me}} \mathbf{C g P - P h}$ shows more complex coordination behaviour. Any future studies involving modification of either phosphoramidites or phosphaadamantane ligands with bulky substituents to deliver more selective catalysts need to ensure the desired Rh catalysts are generated.

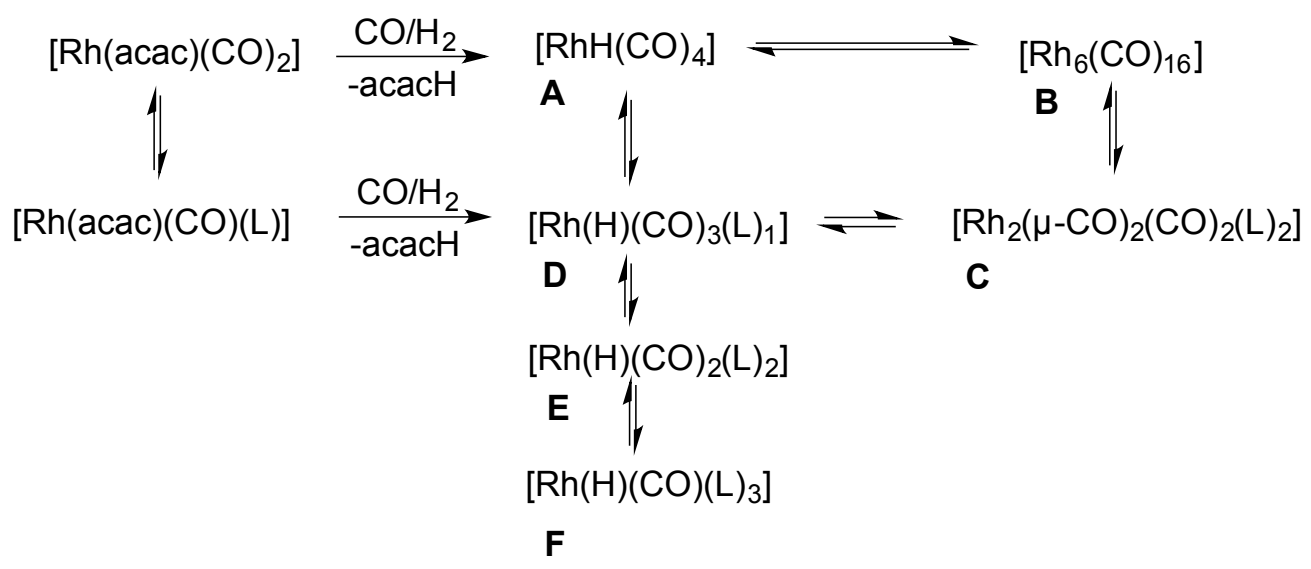

Scheme 1: Formation of catalyst resting states from $\left[\mathrm{Rh}(\mathrm{acac})(\mathrm{CO})_{2}\right]$ and monophosphine ligands: It is proposed that the equilibrium heavily favours unmodified species, A, and $\mathbf{B}$ for bulky ligands 2, and 1-Np3 P. the other ligands discussed form mixtures containing varying proportions of compounds $\mathbf{C}-\mathbf{F}$.

\section{Experimental}

All manipulations were carried out under an inert atmosphere of nitrogen or argon using standard Schlenk techniques. Solvents, $N$-Methylpyrrolidine, triethylamine and $\mathrm{CDCl}_{3}$ were dried and degassed before use. Common starting materials were 
purchased commercially and used as received. Propene/CO/H $/ \mathrm{H}_{2}(10 / 45 / 45)$ and $\mathrm{CO} / \mathrm{H}_{2}$ were obtained from BOC.

$\left.\left[\mathrm{Rh}_{2} \text { (2-ethylhexanoate) }\right)_{4}\right]$ as a $1 \%$ solution in 2,2,4-trimethyl-1,3-pentanediol monoisobutyrate was provided by Eastman Chemical Company. $\left[\mathrm{Rh}(\mathrm{acac})(\mathrm{CO})_{2}\right]$ and ligands 1-Np3 P were purchased. ${ }^{\mathrm{Me}} \mathbf{C g P - P h}$ is available from Strem Chemicals. Ligands (rac)-1 (59\% yield), 3 (14\% yield) were made according to Route A (Scheme 2), while ligand (rac)-2 (71\% yield), was made according to Route B (see ESI for full details and characterisation data).

Route A: Ligands rac-1, 3

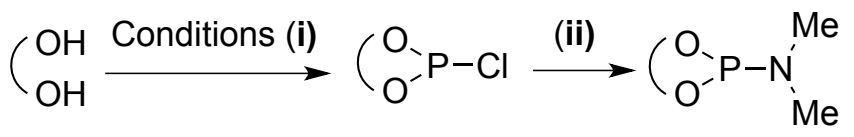

Route B: Ligand rac-2

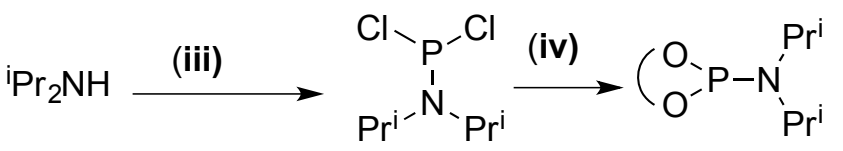

Scheme 2: Ligand synthesis. Conditions: (i): $N$-methylpyrrolidine (3 equiv.), $\mathrm{PCl}_{3}$ (1.3 equiv.), toluene, rt, $48 \mathrm{~h}$. (ii): $N$-methylpyrrolidine (1.2 equiv.), $\mathrm{HNMe}_{2}(1.2$ equiv.), toluene, rt, $18 \mathrm{~h}$. (iii): $\mathrm{Et}_{3} \mathrm{~N}$ (1.5 equiv.), $\mathrm{PCl}_{3}$ (1.5 equiv.), $\mathrm{CH}_{2} \mathrm{Cl}_{2}, \mathrm{rt}, 18 \mathrm{~h}$. (iv): $\mathrm{Et}_{3} \mathrm{~N}$ (1.5 equiv.), diol ( 0.8 equiv.), $\mathrm{CH}_{2} \mathrm{Cl}_{2}, \mathrm{rt}, 18 \mathrm{~h}$.

\section{General procedure for hydroformylation of propene.}

Hydroformylation reactions were performed in a Parr 4590 Micro Reactor fitted with a gas entrainment stirrer, comprising of a hollow impeller, to enhance gas-liquid mass transfer. Ligand (20.48 $\mu \mathrm{mol}(\mathrm{Rh}: \mathrm{L} \mathrm{1:4))}$ was added to a Schlenk tube, which was then purged with nitrogen. $\left[\mathrm{Rh}(\mathrm{acac})(\mathrm{CO})_{2}\right](5.12 \mu \mathrm{mol})$ was added in a toluene stock solution $\left(2 \mathrm{mg} \mathrm{mL}^{-1}\right)$. Toluene was then added to make up to $20 \mathrm{~mL}$ total volume, and internal standard 1-methylnaphthalene $(0.2 \mathrm{~mL})$ was added. The solution was transferred via syringe to the pressure vessel (which had been purged with $\mathrm{CO} / \mathrm{H}_{2}$ ) through the injection port. $\mathrm{CO} / \mathrm{H}_{2}(1: 1,20$ bar $)$ was added and the heating jacket set to $90{ }^{\circ} \mathrm{C}$ while stirring. Once the temperature reached $90{ }^{\circ} \mathrm{C}$, the reaction was stirred for 1 hour to fully activate the catalyst. Then pressure was then released and replaced with propene $/ \mathrm{CO} / \mathrm{H}_{2}(10: 45: 45,20$ bar). The reaction was then run for 1 hour, before immediate GC analysis. 


\section{General procedure for HPIR analysis.}

HPIR studies were performed in a Parr high pressure IR CSTR vessel constructed from Hastelloy $\mathrm{C}$, fitted with $\mathrm{CaF}_{2}$ windows and rated to 275 bar. The adjustable path-length was set to $4 \mathrm{~mm}$. Spectra were recorded using an Avatar 360 FT-IR spectrometer with a mercury-cadmium-telluride detector. [ $\left.\mathrm{Rh}(\mathrm{acac})(\mathrm{CO})_{2}\right](0.06$ mmol) and ligand $(0.075 \mathrm{mmol}(\mathrm{Rh}: \mathrm{L} 1: 4)$ were added to a Schlenk tube, which was then purged with nitrogen. Hexanes $(30 \mathrm{~mL})$ was added to dissolve rhodium and ligand, and then transferred via syringe to the pressure vessel (which had been purged with $\mathrm{N}_{2}$ ) through the injection port. $\mathrm{CO} / \mathrm{H}_{2}(1: 1,20$ bar) was added and the heating jacket set to the desired temperature while stirring. Once the vessel reached the desired temperature a spectrum was recorded every two to 15 minutes. A background spectrum of hexane under appropriate temperature and pressure of $\mathrm{CO} / \mathrm{H}_{2}$ was subtracted from the spectra for analysis.

Acknowledgements: We thank the Eastman Chemical Company for funding of $\mathrm{RCH}$, EPSRC for funding of PD (EP003868/1, and for the use of the national mass spectrometry service at Swansea, Dr Jon Penney and Dr Mesfin Janka for helpful discussions, and all the technical staff in the School of Chemistry for their support.

\section{References}

1. van Leeuwen, P. W. N. M. Claver, C. (Eds.) Rhodium Catalysed Hydroformylation; Kluwer Academic Publishers: Netherlands, 2000.

2. (a) Franke, R. Selent, D. Börner, A. Chem. Rev. 112 (2012) 5675. (b) Börner, A.; Franke, R., Hydroformylation: fundamentals, processes, and applications in organic synthesis; Wiley-VCH, Weinheim, Germany, 2016.

3. (a) Longsma, T. Challa, G. van Leeuwen, P. W. N. M. J. Organomet. Chem. 421 (1991) 121; b) Kubis, C. Selent, D. Sawall, M. Ludwig, R. Neymeyr, K. Baumann, W. Franke, R. Börner, A., Chem. Eur. J. 18 (2012) 8780; c) van Rooy, A. Orji, E. N. Kamer, P. C. J. van Leeuwen, P. W. N. M., 
Organometallics, 14 (1995) 34; see also: Selent, D. Wiese, K-D. Röttger, D. Börner, A., Angew. Chem. Int. Ed., 39 (2000) 1639.

4. a) Besset, T.; Norman, D. W; Reek, J. N. H. Adv. Synth. Catal., 355 (2013) 348. b) Slagt, V. F. Kamer, P. C. J. van Leeuwen, P. W. N. M.; Reek, J. N. H. J. Am. Chem. Soc. 126 (2004) 1526; c) Norman, D. W. Reek, J. N. H. Besset, T. R. M. L. US Pat. 8710275B2, 2014; d) Bellini, R.; Chikkali, S. H.; Berthon-Gelloz, G.; Reek, J. N. H. Angew. Chem., Int. Ed. 50 (2011) 7342; e) Bellini, R., Reek, J. N. H.; Chem. Eur. J., 18 (2012) 13510.

5. (a) Caporali, M. P. Frediani, P. Salvini, A. Laurenczy, G., Inorg. Chim. Acta, 357 (2004) 4537; (b) Dieguez, M. Claver, C. Masdeu-Bulto, A. M. Ruiz, A. van Leeuwen, P. W. N. M. Shoemaker, G. C., Organometallics 18 (1999) 2107.

6. a) Clarke, M. L., Curr. Org. Chem. 9 (2005) 701. b) Noonan, G. M. Newton, D. Cobley, C. J. Suárez, A. Pizzano, A. Clarke, M. L., Adv. Synth. Catal. 352 (2010) 1047; c) Clarke, M. L. Roff, G. J., Chem. Eur. J. 12 (2006) 7978; d) Baber, R. A. Clarke, M. L. Heslop, K. M. Marr, A. C. Orpen, A. G. Pringle, P. G. Ward, A. Zambrano-Williams, D. E. Dalton Trans. (2005) 1079; e) Clarke M. L. Roff, G. J., Green Chem. 9 (2007) 972; f) Noonan, G. M. Fuentes, J. A.; Cobley, C. J. Clarke, M. L., Angew. Chem., Int. Ed., 51 (2012) 2477; g) Noonan, G. M. Cobley, C. J. Mahoney, M. Clarke, M. L., Chem. Commun. 50 (2014) 1475; h) How, R. C. Hembre, R. Ponasik, J. A. Tolleson, G. S. Clarke, M. L., Catal. Sci. Technol., 6 (2016) 118.

7. Hua, Z. Vassar, V. C. Choi, H. Ojima, I. Proc. Natl. Acad. Sci. U. S. A. 101 (2004) 5411.

8. a) Cobley, C. J. Gardner, K. Klosin, J. Praquin, C. Hill, C. Whiteker, G. T. Zanotti-Gerosa, A., J. Org. Chem. 69 (2004) 4031; b) Lambers-Verstappen, M. M. H.; de Vries, J. G. Adv. Synth. Catal. 345 (2003) 478.

9. Dabbawala, A. A.; Jasra, R. V.; Bajaj, H. C. Catal. Commun. 12 (2011) 403.

10. (a) van der Veen, L. A. Boele, M. D. K. Bregman, F. R. Kamer, P. C. J. van Leeuwen, P. W. N. M. Goubitz, K. Fraanje, J. Schenk, H. Bo, C., J. Am. Chem. Soc. 120 (1998) 11616; (b) Czauderna, C. F. Cordes, D. B. Slawin, A. M. Z. Müller, C. van der Vlugt, J. I. Vogt, D. Kamer, P. C. J., Eur. J. Inorg. Chem. (2014) 1797-1810; (c) Schmist, S. Abkai, G. Rosendahl, T. Rominger, F. Hofmann, P. Organomet. 32 (2013) 1044; (d) del Río, I. de Lange, W. G. J. 
van Leeuwen, P. W. N. M. Claver, C. J. Chem. Soc., Dalton Trans. (2001), 1293; (e) del Río, I. Pàmies, O. van Leeuwen, P. W. N. M. Claver, C. J. Organomet. Chem. 608, (2000) 115; (f) Li, Y-Q. Wang, P. Zhang, H. Zhao, X-L. Lu, Y. Popović, Z. Liu, Y. J. Mol. Catal. Sect. A Chem., 402 (2015) 37; (g) Chikkali, S. H. van der Vlugt, J. I. Reek, J. N. H. Coord. Chem. Rev., 262 (2014) 1-15; (h) Rafter, E.; Gilheany, D. G.; Reek, J. N. H.; van Leeuwen, P. W. N. M. ChemCatChem, 2 (2010) 387; (i) Tricas, H. Diebolt, O. van Leeuwen, P. W.N.M. J. Catal., 298 (2013) 198; (j) van der Slot, S. C. Kamer, P. C. J. van Leeuwen, P. W.N.M. Iggo, J. A. Heaton, B. T. Organomet., 20 (2001) 430; Kamer, P. C. J. van Rooy, A. Schoemaker, G. C. van Leeuwen, P. W. N. M., Coord. Chem. Rev. 248 (2004) 2409.

11. Allian, A. D. Garland, M. Dalton Trans. (2005) 1957.

12. Garland, M.; Pino, P. Organometallics 10 (1991) 1693.

13. (a) Downing, J. H. Floure, J. Heslop, K, Haddow, M. F. Hopewell, J. Lusi, M. Phetmung, H. Orpen, A. G., Pringle, P. G., Pugh, R. T. Zambrano-Williams, D. Organomet. 27 (2008) 3216. (b) Ahlers, W., Slany, M. (2001) WO2001/85662 (BASF); (c) Fey, N. Garland, M. Hopewell, J. P., McMullin, C. L., Mastroianni, S., Orpen, A. G., Pringle, P. G. Angew. Chem. Int. Ed. 51 (2012) 118 . 
Composition of catalyst resting states of hydroformylation catalysts derived from bulky mono-phosphorus ligands, rhodium dicarbonyl acetylacetonate and syngas.

Rebecca C. How ${ }^{\mathrm{a}}$, Paul Dingwall ${ }^{\mathrm{a}}$, Robert T. Hembre ${ }^{\mathrm{b}}$, James A. Ponasik ${ }^{\mathrm{b}}$, Ginette S. Tolleson ${ }^{\mathrm{b}}$ and Matthew L. Clarke ${ }^{\mathrm{a} *}$
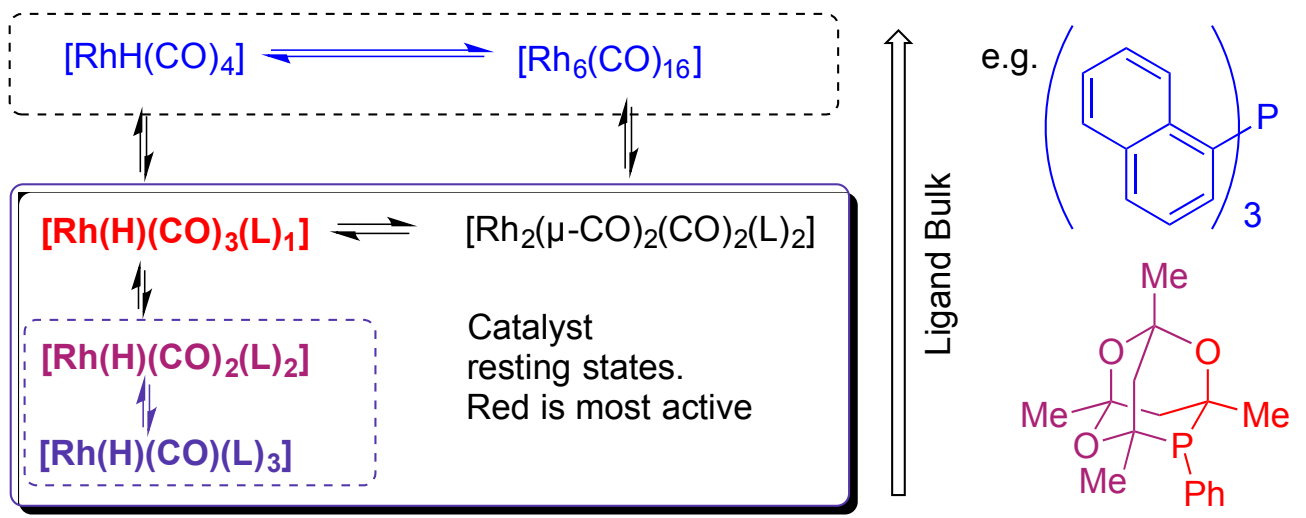

Highlights:

- In situ spectroscopic study of hydroformylation catalysts at typical reaction concentrations.

- Two ligands in the literature found to not coordinate to rhodium in the presence of syngas.

- The highly active $\mathrm{Rh} /$ 1,3,5,7-Tetramethyl-6-phenyl-2,4,8-trioxa-6phosphaadamantane catalyst system studied by in situ HPIR spectroscopy and found to be mixture of resting states, with the composition tuneable by reaction conditions. 